\title{
Screening, Isolation and Identification of Thermophilic Esterase Enzyme Isolated from Rhodococcus SP: LKE-021
}

\section{Lekha Singh $^{1,2}\left(\mathbb{D}\right.$, Gaurav Sharma ${ }^{1 *}(\mathbb{D})$, Gyanendra Awasthi $^{2}(\mathbb{D})$, Lokendra Kumar ${ }^{2,3}(\mathbb{D}$, Mohammad Irfan Ali ${ }^{1}$ iD and Sarmad Moin ${ }^{1}$ (D)}

${ }^{1}$ School of Applied Sciences, Suresh Gyan Vihar University, Jaipur - 302 033, India. 2Department of Biochemistry, Dolphin PG Institute of Biomedical and Natural Science, Dehradun - 248 007, India. ${ }^{3}$ Department of Microbiology, PM College of Education Karsua, Aligarh - 202 001, India.

\begin{abstract}
Rhodococcus sp. LKE-021 from soil samples of the region of Gangotri (10,000 feet of average height) of Uttarakhand Himalayas, India, produced a thermophilic esterase. The physiological and morphological characteristics of the isolated Rhodococcus sp. LKE-021 detected as Gram Positive, rod shape, catalase positive, indole negative, positive to glucose and xylose fermentation test, and can grow on the Nutrient Broth medium. Esterase production confirmed on the basis of spectrophotometric enzyme assay. Taxonomic characteristics Rhodococcus confirmed by 16 s rRNA gene sequencing.

Keywords: Esterase, hydrolytic enzymes, Rhodococcus, LKE -021, extremophiles enzyme, thermophilic enzyme.
\end{abstract}

*Correspondence: gaurav.sharma@mygyanvihar.com; +91-9460032444

(Received: 03 September 2019; accepted: 24 September 2019)

Citation: Lekha Singh, Gaurav Sharma, Gyanendra Awasthi, Lokendra Kumar, Mohammad Irfan Ali and Sarmad Moin, Screening, Isolation and Identification of Thermophilic Esterase Enzyme Isolated from Rhodococcus SP: LKE-021, J Pure Appl Microbiol., 2019; 13(3): 1855-1861. https://doi.org/10.22207/JPAM.13.3.63

(c) The Author(s) 2019. Open Access. This article is distributed under the terms of the Creative Commons Attribution 4.0 International License which permits unrestricted use, sharing, distribution, and reproduction in any medium, provided you give appropriate credit to the original author(s) and the source, provide a link to the Creative Commons license, and indicate if changes were made. 


\section{INTRODUCTION}

Esterase is a hydrolytic enzyme found in multiple forms occurring with broad substrate specificity. The hydrolysis of organic esters catalyzing by Esterase. Esterase are surviving in the environment due to their capability. They are extensively distributed in animals, microorganisms and plants. Numerous of them exhibits atolerance against varied substrate which led to the postulation that they have developed to allow access to sources of carbon or to be incorporated in catabolic pathways. Furthermore, esterases also exhibit extraordinary stereospecificity, therefore in fine-chemicals synthesis this enzyme used asstriking enzymes for the synthesis of optically active pure compounds ${ }^{1-6}$. Esterase have another tremendous properties i.e. active and stable in organic solvents which make the unique as there is no need of cofactors ${ }^{7}$. Esterase are broadly used in the food, cosmetic, perfume, chemical, pharma and agricultural industries, by reason of exclusive characteristics like resistant to organic solvents, stereo and substrate specificity ${ }^{8-10}$. Though, nearby some obstructions still to be there for the large scale utilization of esterases in industries, for instance low yield of production, thermal stability, limited $\mathrm{pH}$, and deprived performance in organic solvents ${ }^{11,12}$. There is still need of enhanced their catalytic efficiency on the basis of rational protein design through functional modification of the enzymes in addition to substrate specificity, thermostability and enantioselectivityas required by industries ${ }^{13-16}$. Better understanding of structure and functionalities will also ease rational improvement in purification, isolation and source of microbes. Development of new microbial esterase enzyme is very important in Industrial Application. Esterase are the used extensively in food, pharmaceutical, food and chemical fields. While the thermostable amylaseare widely used in starch Industry in various stages of developments ${ }^{17}$. Industrial and scientific significance of these extremophilic enzyme in recent years has increased excessively due to structural and functional stability of their proteins ${ }^{12}$.

\section{EXPERIMENTAL METHODOLOGY}

Microorganism: Identification and culture conditions
Pure bacterial culture isolated from soil sample collected from Gangotri region $(10,000$ feet of average height) of Himalaya, Uttarakhand (India). Before inoculation in sterile distilled water $(5 \% \mathrm{w} / \mathrm{v})$ collected soilsample dried for $72 \mathrm{hat} 80^{\circ} \mathrm{C}$. Serial dilution performed and aqueous phase was collected and inoculation carried out into nutrient broth (NB). The composition of NB (pH 7.0, gL$\left.{ }^{1}\right)$ : peptone - 5.0; $\mathrm{NaCl}-5.0$; yeast extract- 3.0; glucose - 10.0. The Plates were incubated for 5 daysat $60^{\circ} \mathrm{C}$. Randomly colonies were selected on tributyrin agar plate and screened for esterolytic activity in solidified NB containing $1.5 \%$ tributyrin for 3 days at $60^{\circ} \mathrm{C}$. After 4 days of cultivation at $40^{\circ} \mathrm{C}$ a bright clear zone on tributyrin agar plate achieved $^{18}$. Master culture preserved in glycerol $(40 \% \mathrm{v} / \mathrm{v})$ at $-80^{\circ} \mathrm{C}$ for future use. Identification of bacteria performed by 16s rDNA method of sequencing. Purification and Extraction of DNA were performed by Sigma kit (GenElute ${ }^{\mathrm{TM}}$ bacterial genomic DNA), as per the instructions given by manufacturer. Primers 5'-CAGGCCTAACACATGCAAGTC as forward primerand 5'-GGGCGGWGTGTACAAGGC as reverse primer used for PCR amplification experiments. Amplified DNA was purified by Sigma DNA kit (GenElute ${ }^{\mathrm{TM}}$ bacterial genomic). sequences available in NCBI database used for 16S rDNA sequencingby using clustalW, and TREEVIEW program (3.0) used for depict phylogenetic position of the isolate. Isolated strain was identified as Rhodococcus $s p$. LKE-021 by partial $16 \mathrm{~S}$ rDNA gene sequencing.

\section{Quantification and production of Enzyme}

Rhodococcus sp. LKE-021 was inoculated

in shake flasks method containing modified NB (pH 7.0) containing (g/l): peptone, 5.0; $\mathrm{NaCl}, 5.0$; yeast extract, 3.0; glucose, 10.0, with constant shaking at $135 \mathrm{rpm}$ at $60^{\circ} \mathrm{C}$ with. After $24 \mathrm{hrs}$, culture was centrifuged at $10^{\prime} 10^{3}$ r.c.f. for $5 \mathrm{~min}$ and extracellular enzyme was recoverin liquid fraction. Activity of esterase enzyme estimated spectrophotometrically by with $p$-nitrophenyl acetate (pNP acetate) as substrate. Enzyme containing $250 \mu \mathrm{L}$ supernatant of culturewas mixed with $200 \mu \mathrm{L}$ of $50 \mathrm{mM}$ Mcllvaine buffer $(\mathrm{pH}$ 7.2 ) and $50 \mu \mathrm{LpNP}$ acetate $(2 \mathrm{mM})$ and incubated for $30 \mathrm{~min}$ at $60^{\circ} \mathrm{C}$. Reaction terminated by adding $500 \mu \mathrm{L}$ of chilled buffer and reaction was immediately terminated. Centrifugation was carried out by centrifuging at $10^{\prime} 10^{3}$ r.c.f. for $5 \mathrm{~min}$ 
and suspended particles were extracted. Amount of released p-nitrophenyl acetate (pNP acetate) measured by hydrolysiscatalyzed by esterase calculated at $\lambda^{410} \mathrm{~nm}$ compared toblank ${ }^{19}$. Total protein was determine by Lowry's method with standard bovine serum albumin (BSA). Protein concentration determine by taking absorbance at $\lambda^{280} \mathrm{~nm}$ during chromatographic purification ${ }^{20}$.

\section{RESULTS}

Collected soil sample tested for its physical-chemical properties and it have $8.5 \mathrm{pH}$, temperature $6^{\circ} \mathrm{C}$, and moisture content $25 \%, \mathrm{w} / \mathrm{v}$. Selection ofEsterasesproducing bacteria

35 soil bacterial pure cultures were isolated from the surroundings of Gangotri region of Uttarakhand Himalaya, India. These isolates showed potential for esterolytic activity and amongst them most potent,one isolate used for further work.

Primary Screening thermophilic enzyme producing thermophile microorganisms based on qualitative test

Isolate screened of novel thermophilicactivity on agar plate containing $1.5 \%$ of tributyrin in NB (composition in $\mathrm{g} / \mathrm{L}$; beef

Table 1. Results of various tests performed to identify the microorganisms

\begin{tabular}{|c|c|c|}
\hline Tests name & & Results \\
\hline Gram-staining & & Positive \\
\hline Endospore staining & & Positive \\
\hline Shape & & Rod \\
\hline Motility & & Motile \\
\hline \multirow[t]{2}{*}{ Anaerobic growth } & Glucose & Positive \\
\hline & Xylose & Negative \\
\hline Carbohydrate & Glucose & Positive \\
\hline \multicolumn{3}{|l|}{ Fermentation } \\
\hline & $\begin{array}{l}\text { Sucrose } \\
\text { Lactose }\end{array}$ & $\begin{array}{l}\text { Positive } \\
\text { Negative }\end{array}$ \\
\hline & Mannitol & Positive \\
\hline \multicolumn{2}{|l|}{ Indole production test } & Positive \\
\hline \multicolumn{2}{|l|}{ Methyl red test } & Positive \\
\hline \multicolumn{2}{|l|}{ Citrate utilization test } & Negative \\
\hline \multicolumn{2}{|l|}{ Voges Proskauer test } & Positive \\
\hline \multicolumn{2}{|l|}{ Catalase test } & Positive \\
\hline \multicolumn{2}{|l|}{ Urease test } & -ve \\
\hline \multirow{3}{*}{$\begin{array}{l}\text { TSI agar test for } \mathrm{H}_{2} \mathrm{~S} \\
\text { production } \\
\text { Casein hydrolysis test }\end{array}$} & Slant & Alkaline \\
\hline & Butt & Acidic \\
\hline & & -ve \\
\hline
\end{tabular}

extract 3; peptone 5; $\mathrm{NaCl} 5$; glucose 10; agar agar 20; pH 7.2-7.4) incubatedat $60^{\circ} \mathrm{C}$ for three days. Further incubation at $4^{\circ} \mathrm{C}$ for 4 days was done to bright clear zone on the agar plate (Fig. 1).

Biochemical characterization of Rhodococcus sp. LKE-021

In order to identify the microorganisms various microbiological and biochemical tests were performed and their results are summarized in a tabular manner (Table 1).

The physiological and morphological features of the strain Rhodococcus sp. LKE-021 was detected as Gram positive (Fig. 2), rod, positive to catalase, negative to indole test, positive against fermentation test for glucose and xylose, which can grow in the Nutrient Broth medium (OD at $600=0.679$ [1:20 dilution], after $22 \mathrm{~h}$ ). Taxonomic characterization was describe based on the $16 \mathrm{~S}$ rRNA gene nucleotide sequences.

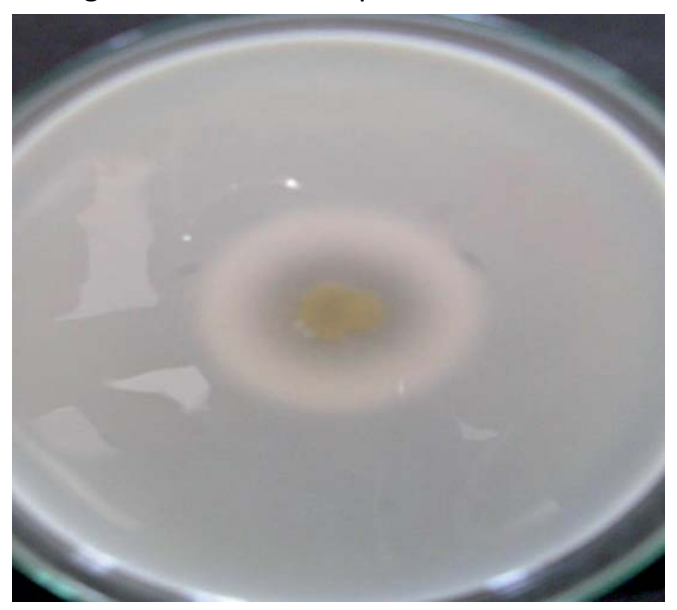

Fig. 1. Primary screening of thermophilic enzyme producing bacteria

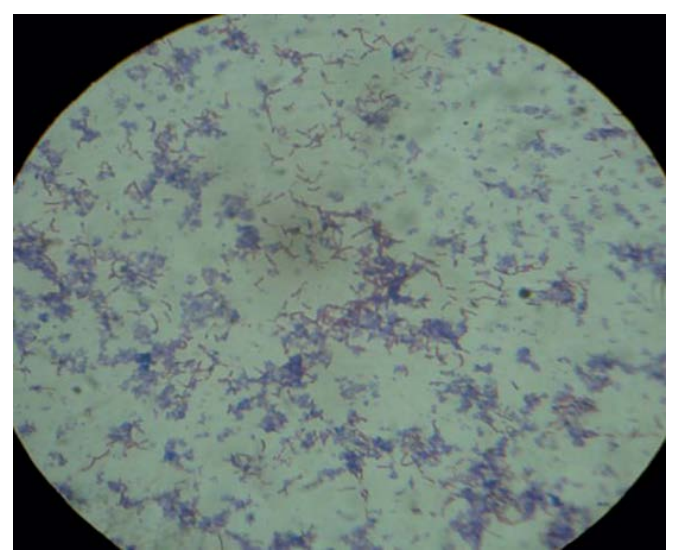

Fig. 2. Gram straining of Rhodococcus sp. LKE-021 


\section{Optimization of enzyme production}

Esterase production was optimized with nutrient broth. $100 \mathrm{ml}$ nutrient broth inoculated with Rhodococcus sp. LKE-021 and incubated in $60^{\circ} \mathrm{C}$ at $120 \mathrm{rpm}$. Samples were collected from $0 \mathrm{~h}$ to $60 \mathrm{~h}$ after every $2 \mathrm{~h}$ of interval and all the parameters like enzyme production, total protein, growth profile, carbon utilization, estimated of total biomass production in order to optimize standard enzyme production time and condition in shake flask determined. It was observed that maximum activity was attained at around $22 \mathrm{~h}$ along with maximum protein production (Fig. 3 \& 4). The Rhodococcus sp. LKE-021 was at early log phase and total biomass was almost stable. More than $80 \%$ sugar (sole carbon source) has been utilized by that time (Fig. 5). Rhodococcus sp. LKE-021 was incubated in modified nutrient broth for 48 hour after inoculation at $37^{\circ} \mathrm{C}$ in incubator shaker at 120 r.p.m. for further laboratory scale purification.

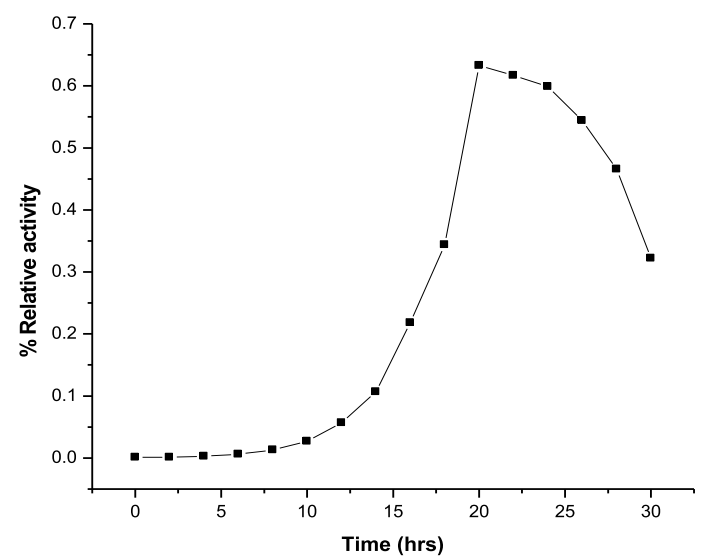

Fig. 3. Growth curve of Rhodococcus sp. LKE-021 (O.D. at $600 \mathrm{~nm}$ ) at shake flask level

\section{Molecular Identification of LKE-021}

NCBI database was used for 16S rRNA sequence alignment using clustalW software, and the phylogenetic tree prepared by the TREEVIEW program. Sequenced16S rRNA gene containing $1425 \mathrm{bp}$ was submitted to NCBI GenBank database. Based on the nucleotide sequences of $16 \mathrm{~S}$ rRNA gene the stain Rhodococcus sp. LKE-021 was classified as a new Rhodococcussp isolate. The taxonomic position is revealed in the phylogenetic tree (Fig. 6). The ribosomal protein homology as

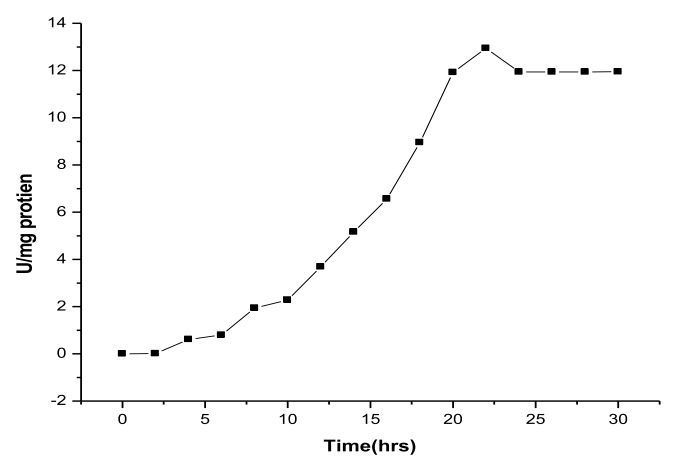

Fig. 4. Enzyme production of Rhodococcus sp. LKE-021 (U/mg) at shake flask level

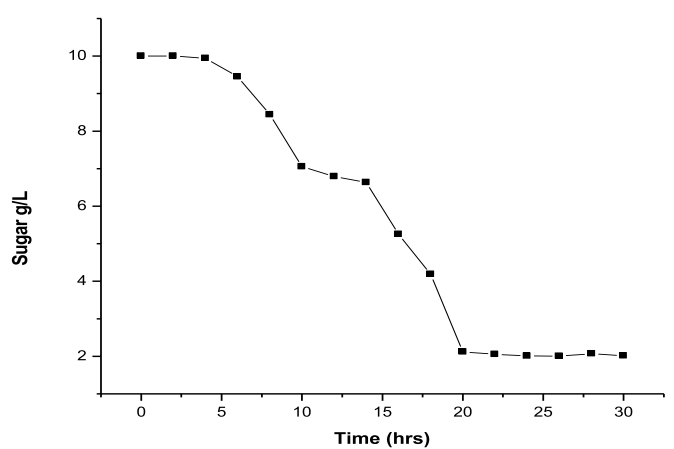

Fig. 5. Sugar utilization of LKE-021 (g/L) at shake flask level

Table 2. Alignment view using combination of NCBI GenBank and RDP database of strain RhodococcusspLKE-021

\begin{tabular}{|c|c|c|l|}
\hline Alignment View & RDP ID & $\begin{array}{c}\text { Alignment } \\
\text { Result }\end{array}$ & \multicolumn{1}{|c|}{ Sequence description } \\
\hline$\square$ & LKE-021 & $\mathbf{0 . 9 7}$ & studied Sample \\
\hline$\square$ & X76690 & $\mathbf{0 . 9 9}$ & Rhodococcus sp. str. PH114 \\
\hline & AJ131637 & $\mathbf{0 . 9 9}$ & $\begin{array}{l}\text { Rhodococcus erythropolis str. } \\
\text { DCL14 }\end{array}$ \\
\hline$\square$ & U87968 & $\mathbf{0 . 9 9}$ & Rhodococcus X309 str. X309 \\
\hline & U82666 & $\mathbf{0 . 9 9}$ & Nocardioides simplex ATCC 19565 \\
\hline & U82667 & $\mathbf{0 . 9 9}$ & Nocardioides simplex ATCC 19566 \\
\hline$\square$ & X79289 & $\mathbf{0 . 9 9}$ & $\begin{array}{l}\text { RhodococCus erythropolis DSM } \\
\text { 43066 (T) }\end{array}$ \\
\hline$\square$ & AF181691 & $\mathbf{0 . 9 9}$ & Rhodococcus 7/1 str. 7/1 \\
\hline$\square$ & AB010911 & $\mathbf{0 . 9 9}$ & Rhodococcus sp. str. SRB1948-A07 \\
\hline$\square$ & U81990 & $\mathbf{0 . 9 9}$ & Nocardioides simplex ATCC 13260 \\
\hline$\square$ & X76691 & $\mathbf{0 . 9 9}$ & Rhodococcus erythropolis \\
\hline
\end{tabular}




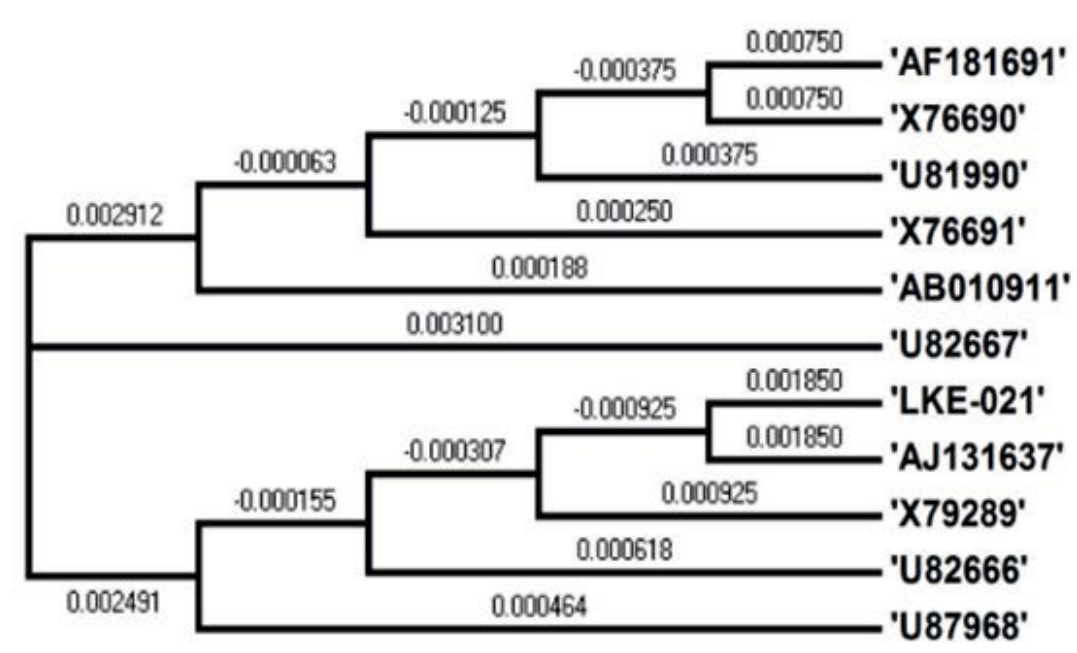

Fig. 6. Dendrogram indicating the position of the Rhodococcus sp LKE-021

well as similarity matrix was also reduced based on Nucleotide Sequence Homology of Rhodococcus sp. LKE-021 Using Kimura-2 Parameter. Alignment view via combination of RDP database and NCBI GenBank of Rhodococcussp LKE-021shown in
Table 2. Nucleotide distance (below diagonal) and similarity (above diagonal) identities among the studied sample 'LKE-021' and ten other closest homologs microorganism indicates in Table 3.

Table 3. Distance Matrix of Rhodococcussp LKE-021based on Nucleotide Sequence Homology

\begin{tabular}{|l|c|c|c|c|c|c|c|c|c|c|c|c|}
\hline \multicolumn{10}{|l|}{ Distance Matrix } \\
\hline & & 1 & 2 & 3 & 4 & 5 & 6 & 7 & 8 & 9 & 10 & 11 \\
\hline LKE-021 & 1 & $\ldots$ & 0.990 & 0.996 & 0.990 & 0.996 & 0.990 & 0.996 & 0.996 & 0.990 & 0.996 & 0.989 \\
\hline AF181691 & 2 & 0.010 & $\ldots$ & 0.994 & 1.00 & 0.994 & 1.00 & 0.994 & 0.994 & 1.00 & 0.994 & 0.999 \\
\hline AJ131637 & 3 & 0.004 & 0.006 & $\ldots$ & 0.994 & 1.00 & 0.994 & 1.00 & 1.00 & 0.994 & 1.00 & 0.993 \\
\hline U81990 & 4 & 0.010 & 0.000 & 0.006 & $\ldots$ & 0.994 & 1.00 & 0.994 & 0.994 & 1.00 & 0.994 & 0.999 \\
\hline X79289 & 5 & 0.004 & 0.006 & 0.000 & 0.006 & $\ldots$ & 0.994 & 1.00 & 1.00 & 0.994 & 1.00 & 0.993 \\
\hline X76691 & 6 & 0.010 & 0.000 & 0.006 & 0.000 & 0.006 & $\ldots$ & 0.994 & 0.994 & 1.00 & 0.994 & 0.999 \\
\hline U82666 & 7 & 0.004 & 0.006 & 0.000 & 0.006 & 0.000 & 0.006 & $\ldots$ & 1.00 & 0.994 & 1.00 & 0.993 \\
\hline U87968 & 8 & 0.004 & 0.006 & 0.000 & 0.006 & 0.000 & 0.006 & 0.000 & $\ldots$ & 0.994 & 1.00 & 0.993 \\
\hline AB010911 & 9 & 0.010 & 0.000 & 0.006 & 0.000 & 0.006 & 0.000 & 0.006 & 0.006 & $\ldots$ & 0.994 & 0.999 \\
\hline U82667 & 10 & 0.004 & 0.006 & 0.000 & 0.006 & 0.000 & 0.006 & 0.000 & 0.000 & 0.006 & $\ldots$ & 0.993 \\
\hline X76690 & 11 & 0.011 & 0.002 & 0.007 & 0.002 & 0.007 & 0.002 & 0.007 & 0.007 & 0.002 & 0.007 & $\ldots$ \\
\hline
\end{tabular}

\section{DISCUSSION}

Few of extremophilic esterase enzyme have been reportedfrom thermophiles, but there areinsufficient report of esterase enzyme activity from Rhodococcus sp. ${ }^{21-23}$ reported. In current research work we are reporting the hyperthermo alkaline esterase enzyme isolated from Rhodococcus sp LKE-021, isolated from soil sample of Gangotri region of Himalaya Uttarakhand, India. Esterase production was optimized with nutrient brothfrom Rhodococcus sp LKE-021. Based on sequences of nucleotide 16s rRNA gene sequence of the strain found to be member of Rhodococcus sp LKE-021. LKE-021. Esterase studied by using various PNP and ethyle ester of straight chain of fatty acid and ranging of the chain from $C_{2}$ to $C_{14}$. Esterase showed specificity to substratelikep NP and ethyle ester. pNP and ethyle ester with acyle chain bigger length than $\mathrm{C}_{8}$ were not suitable substrate for LKE-021. 
Taxonomic position of the LKE-021 was showed in phylogenetic tree.

Kumar et al., also isolated esterase from thermoalkaliphilic halotolerant Rhodococcus sp. LKE- $028^{12}$. Known microbial enzymes are to play animportant role as metabolic catalysts, various uses in different industries and applications. The use market for industrial important enzymes is widely spread with various industrial commercial level applications. Many industrial products are madeup using enzymes. Many industrial processes, using chemical synthesis for pharmaceuticals, chemical, drug and food production have several disadvantages: devoid of enantiomeric specificity for chiral synthesis, low catalytic activity, need for low $\mathrm{pH}$, high temperature and high pressure. Thermostable esterase are very important for the industrial process, such as drug industry, agricultural industry, food industry, cosmetic industry, pharmaceutical industry etc. Some thermostable esterase had been earlier reported such as thermophilic Anoxybacillus gonensis-A4 bacterium isolated from hot springs in Turkey ${ }^{24}$, carboxyl esterase enzyme originated from Bacillus subtilis have used in the synthesis of naproxen for instance there isno steroidal anti-inflammatory drug $^{18}$ and 2-arylpropionic acids having high enantio-selectivity ${ }^{25}$, Bacillus coagulans ${ }^{26}$, Bacillus stearothermophilus ${ }^{27}$. Recently, diphenolases were studied from Anoxybacillus kestanbolensis strains $\mathrm{K} 1$ and $\mathrm{K} \mathrm{T}^{28}$ as they all produced thermophile esterase. Rhodococcus $s p$. LKE-021 is batter then all strains because LKE-021 Esterase shows the activity on higher temperature i.e. $70^{\circ} \mathrm{C}$ and it is stable on $80-90^{\circ} \mathrm{C}$.

\section{ACKNOWLEDGMENTS}

The authors are sincerely thankful to Mr. Sunil Sharma, Chancellor, and Dr. Sudhanshu Sharma, Chief Mentor of Suresh Gyan Vihar University, Jaipur, for providing a platform for this research.

\section{CONFLICT OF INTEREST}

The authors declares that there is no conflict of interest.

\section{AUTHORS' CONTRIBUTION}

LS collected sample and isolation of Rhodococcus sp.. GS did DNA extraction and performed PCR. GA did 16S rDNA sequencing. LK did quantification and production of Enzyme. MIA checked grammer and formatted the manuscript. SM prepared Phylogenetic tree and analysed.

\section{FUNDING}

None.

\section{DATA AVAILABILITY}

All datasets obtained or studied during this study are incorporated in the manuscript.

\section{ETHICS STATEMENT}

This article does not contain any studies with human participants or animals performed by any of the authors.

\section{REFERENCES}

1. Bornscheuer UT, Kazlauskas RJ. Hydrolases in organic synthesis: regio- and stereoselective biotransformations. Wiley-VCH, Weinheim, 1999.

2. Phytian SJ. Esterases. In: Biotechnology-Series, 1998; Vol. 8a, pp. 193-241. (Rehm, H.J., Reed, G., P hler, A., Stadler, P.J.W. and Kelly, D.R., Eds.), Wiley-VCH, Weinheim.

3. Patel RN. Stereoselective Biocatalysis. Marcel Dekker, New York, 2000. https://doi. org/10.1201/9781420027242

4. Faber K. Biotransformations in Organic Chemistry, Springer, Berlin, 2000. https://doi.org/10.1007/9783-642-98071-8

5. Drauz K, Waldmann H. Enzyme Catalysis in Organic Synthesis, 1995; 1 \& 2. Wiley-VCH, Weinheim. https:// doi.org/10.1002/9783527619429

6. Wong $\mathrm{CH}$, Whitesides GM. Enzymes in Synthetic Organic Chemistry. Pergamon Press, Oxford, 1994.

7. Bornscheuer UT. Microbial carboxyl esterases: classification, properties and application in biocatalysis. FEMS Microbiology Reviews, 2002; 26 (1): 73-81. https://doi.org/10.1111/j.1574-6976.2002.tb00599.x

8. Esteban-Torres M, Mancheno JM, de las Rivas B, Munoz R. 2014. Characterization of a cold-active esterase from Lactobacillus plantarum suitable for food fermentations. J. Agric. Food Chem., 2014; 62(22): 5126-5132. https://doi.org/10.1021/jf501493z

9. Nardini M, Dijkstra B W. Alpha/beta hydrolase fold enzymes: the family keeps growing. Curr. Opin. Struct. Biol., 1999; 9(6): 732-737. https://doi.org/10.1016/ S0959-440X(99)00037-8

10. Chen Q, Luan ZJ, Cheng X, Xu JH. Molecular dynamics investigation of the substrate binding 
mechanism in carboxylesterase. Biochemistry, 2015; 54 (9): 1841 - 1848. https://doi.org/10.1016/S0959440X(99)00037-8

11. Byun JS, Rhee JK, Kim ND, Yoon J, Kim DU, Koh E, Oh JW, Cho HS. Crystal structure of hyperthermophilic esterase EstE1 and the relationship between its dimerization and thermostability properties. BMC Struct. Biol., 2007; 7(1),47. https://doi.org/10.1186/1472-6807-747

12. Kumar L, Singh B, Adhikari D K, Mukherjee J, Ghosh D. A thermoalkaliphilic halotolerant esterase from Rhodococcus sp. LKE-028 (MTCC 5562): enzyme purification and characterization. Process biochem, 2012; 47(6): 983-991. https://doi. org/10.1186/1472-6807-7-47

13. Boyineni J, Kim J, Kang BS, Lee C., Jang, SH. Enhanced catalytic site thermal stability of cold-adapted esterase EstK by a W208Y mutation. BiochimBiophys ActaProteins and Proteomics, 2014; 1844(6): 1076-1082. https://doi.org/10.1186/1472-6807-7-47

14. Liu JY, Bian HP, Tang Y, Bai YP, Xu JH. Double substituted variant of Bacillus amyloliquefaciens esterase with enhanced enantioselectivity and high activity towards 1-(32, 42 -methylene- dioxyphenyl) ethyl acetate. Appl. Microbiol Biot., 2015; 99(4): 1701-1708. https:// doi.org/10.1007/s00253-014-5992-0

15. Kim J, Kim S, Yoon S, Hong E, Ryu Y. Improved enantioselectivity of thermostable esterase from Archaeoglobusfulgidus toward (S)-ketoprofen ethyl ester by directed evolution and characterization of mutant esterases. Appl Microbiol Biot., 2015; 99(15): 6293-6301. https://doi.org/10.1007/s00253-0156422-7

16. Zhang $\mathrm{S}, \mathrm{Wu} \mathrm{G}$, Feng $\mathrm{S}$, Liu Z. Improved thermostability of esterase from Aspergillus fumigatus by sitedirected mutagenesis. Enzyme Microb. Technol., 2014; 64(65): 11-16. https://doi.org/10.1016/j. enzmictec.2014.06.003

17. Haki GD, Rakshit SK. Developments in industrially important thermostable enzymes: a review. Bioresour. Technol 2003; 89(1): 17-34. https://doi.org/10.1016/ S0960-8524(03)00033-6

18. Quax WJ, Broekhuizen CP. Development of a new Bacillus carboxyl esterase for use in the resolution of chiral drugs. App/ Microbiol Biot., 1994; 41(4): 425-431. https://doi.org/10.1007/BF00212253

19. Sana B, Ghosh D, Saha M, Mukherjee Z. Purification and characterization of an extremely dimethylsulfoxide tolerant esterase from a salt-tolerant Bacillus species isolated from the marine environment of the
Sundarbans. Process Biochem., 2007; 42(12): 15711578. https://doi.org/10.1016/j.procbio.2007.05.026

20. Lowry OH, Rosebrough NJ, Farr AL, Randall RJ. Protein measurement with the Folin phenol reagent. J. Biol. Chem., 1951; 193: 265-275.

21. Pogorevc M, Strauss UT, Hayn M, Faber K. Novel carboxyl esterase preparations for the resolution of linalyl acetate. Monatshefte fr Chemie., 2000; 131(6): 639-644. https://doi.org/10.1007/s007060070092

22. Bresler MM, Rosser SJ, Basran A,Bruce NC. Gene cloning and nucleotide sequencing and properties of a cocaine esterase from Rhodococcus sp. strain MB1. Appl. Environ. Microbiol., 2000; 66(3): 904-908. https://doi.org/10.1007/s007060070092

23. Rathbone DA, Holt PJ, Lowe CR,Bruce NC. Molecular analysis of the Rhodococcus sp. strain $\mathrm{H} 1$ her gene and characterization of its product, a heroin esterase, expressed in Escherichia coli. Appl. Environ. Microbiol., 1997; 63(5): 2062-2066.

24. Faiz O, Colak A, Saglam N, anakni S, Belduz A $O$. Determination and characterization of thermostable esterolytic activity from a novel thermophilic bacterium Anoxybacillus gonensis A4. BMB Reports, 2007; 40(4): 588-594. https://doi. org/10.5483/BMBRep.2007.40.4.588

25. Azzolina O, Vercesi D, Collina S,Ghislandi V. Chiral resolution of methyl 2-aryloxypropionates by biocatalytic stereospecific hydrolysis. II Farmaco, 1995; 50(4): 221-226.

26. Baumann M, Hauer BH, Bornscheuer UT. Rapid screening of hydrolases for the enantioselective conversion of 'difficult-to-resolve' substrates. Tetrahedron: Asymmetry, 2000; 11(23): 4781-4790. https://doi.org/10.1016/S0957-4166(00)00465-1

27. Molinari F, Brenna O, Valenti M,Aragozzini F. Isolation of a novel carboxylesterase from Bacillus coagulans with high enantioselectivity toward racemic esters of 1, 2-0-isopropyli-deneglycerol. Enzyme Microb. Technol., 1996; 19 (7): 551-556. https://doi. org/10.1016/S0141-0229(96)00066-X

28. Suoniemi A and Tynkkynen S. Cloning and characterization of an esterase from Propionibacterium freudenreichii ssp. shermanii. Le Lait, 2002; 82: 81-89. https://doi.org/10.1051/lait:2001007

29. Yildirim M, Col M, Colak A, G ner S, D Iger S and Id zA $O$ Diphenolases from Anoxybacillus kestanbolensis strains K1 and K4 T. World Journal of Microbiology and Biotechnology, 2005; 21: 501-507. https://doi. org/10.1007/s11274-004-2392-0 